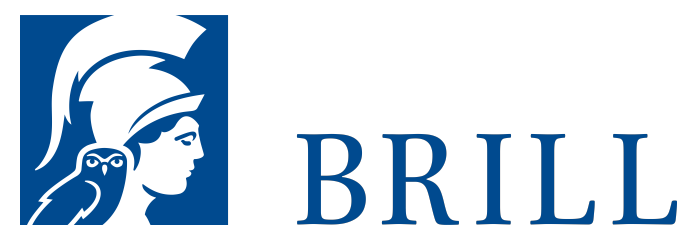

\title{
Diplomatie von Angesicht zu Angesicht
}

Diplomatische Handlungsformen in den deutsch-französischen Beziehungen 1870-1919

Authors: Verena Steller and Steller

Die Macht der Diplomatie liegt in den Methoden der Verhandlungsführung. Mit kulturgeschichtlichem Zugriff fragt diese Studie nach Handlungsmechanismen der Diplomatie und deren Wandel.

Deutsche und französische Botschafter in Paris und Berlin fungierten als Mittler zwischen ihren beiden Souveränen, Regierungen, auswärtigen Diensten und Öffentlichkeiten. Fragen von Konfrontation und Kooperation hatten sie verhandelbar zu machen. Diese innovative Studie zeigt auf, wie symbolische Handlungsformen ihre Leistungsfähigkeit nach dem deutsch-französischen Krieg, in den französisch-russischen Bündnisverhandlungen (189095), in der Suche nach Regeln gegen den Krieg und 1919 in Versailles entfalteten. Selbst in der Vertrauenskrise der Diplomatie galt: Symbolisches Handeln ist nicht Zierrat der Politik - symbolisches Handeln ist Politik.

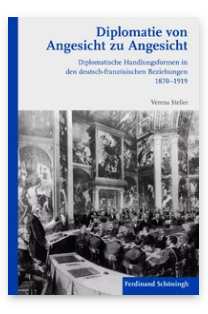

Pages: 557

Seiten

Language:

German

Subjects: Early

Modern History,

History

Publisher: Brill |

Schöningh

E-Book (PDF)

Released online:

O2 Jan 2012

ISBN: 978-3-

657-77166-о

List price

USD \$104.00

Hardback

Publication date:

14 Sep 2011

ISBN: 978-3-

506-77166-7

List price

USD \$104.00 
Verena Steller, Studium der Geschichte, Romanistik und

Kommunikationswissenschaften in Bochum und Paris, z. Zt.

Mitarb. an der GoetheUniversität Frankfurt am Main.

For more information see brill.com

Order information: Order online at brill.com +44 330 333 0049 | customerservices@brill.com Submission information: brill.com/authors

Titles published by Brill |Fink, Brill | mentis or Brill | Schöningh: +49(o)71 5413279216 | brill@brocom.de 